J. Perinat. Med. 15 (1987) 37

\section{Continuous transcutaneous carbon dioxide measurement from the fetal scalp during labor and during first minutes of extrauterine life}

\author{
Olof Löfgren
}

Delivery Ward, County Hospital of Trelleborg, Sweden

\section{Introduction}

Routine fetal surveillance during labor includes the fetal heart rate-uterine contraction (FHR-UC) tracing and intermittent fetal blood respiratory gas evaluation by the SALING technique [11]. New methods for continuous fetal blood gas monitoring, including continuous $\mathrm{pH}$ monitoring [14] and continuous transcutaneous oxygen monitoring $[3,7,15]$ have been published, but currently neither method is fully evaluated or, for the time being, suitable for routine application. The technique for continuous transcutaneous carbon dioxide $\left(\mathrm{tcPcO}_{2}\right)$ monitoring has been shown to reliably reflect changes in the arterial $\mathrm{PcO}_{2}\left(\mathrm{aPco}_{2}\right)$ in newborns $[2,8]$ and adults [13], and the correlation between $\mathrm{tcPcO}_{2}$ and $\mathrm{aPcO}_{2}$ is even higher than for transcutaneous oxygen/arterial oxygen values. Thus the technique for $\mathrm{tcPco}_{2}$ recording is also of interest for obstetricians, and the first case reports with fetal recordings were presented in 1981 [6].

The current investigation reports on the results with $\mathrm{tcPcO}_{2}$ monitoring from the fetal scalp in 25 consecutive vaginal deliveries.

\section{Methods and patients}

The electrode was a Stow-Severinghaus electrode, modified by the incorporation of a heating element to arterialize the capillary circula- tion ${ }^{1}$. Before every recording the electrode was calibrated in $5 \%$ and $10 \% \mathrm{CO}_{2}$, according to the actual barometric pressure. The electrode temperature during calibration and measurement was $44^{\circ} \mathrm{C}$. Before attachment of the electrode the fetal scalp was prepared as described by LöFGREN [6]. A drop of a diffusion jelly was interposed between the skin and the electrode membrane and the electrode was affixed with a glue ${ }^{2}$. The electrode was attached to the fetal scalp in 25 consecutive vaginal deliveries. All pregnancies had been normal, and no complication of labor was expected. The FHR was simultaneously recorded using an ordinary scalp electrode. At delivery the umbilical cord was clamped and umbilical cord blood was analyzed for $\mathrm{PCO}_{2}{ }^{3}$.

\section{Results}

The mean cervical dilatation at attachment of the electrode was $6.5 \mathrm{~cm}$ (range 5-10), and the mean recording time was 136 minutes (range $10-348$, table I). No burns were produced by the electrode temperature of $44^{\circ} \mathrm{C}$. Six patients were measured only in the second stage of labor. In 6 of 25 patients, the electrode fell of or was deliberately removed when the fetal head

\footnotetext{
1 Radiometer, Copenhagen, Denmark

${ }^{2}$ Histoacryl ${ }^{\circledR}$, Braun, Melsungen, W. Germany

3 ABL 2, Radiometer, Copenhagen, Denmark
} 


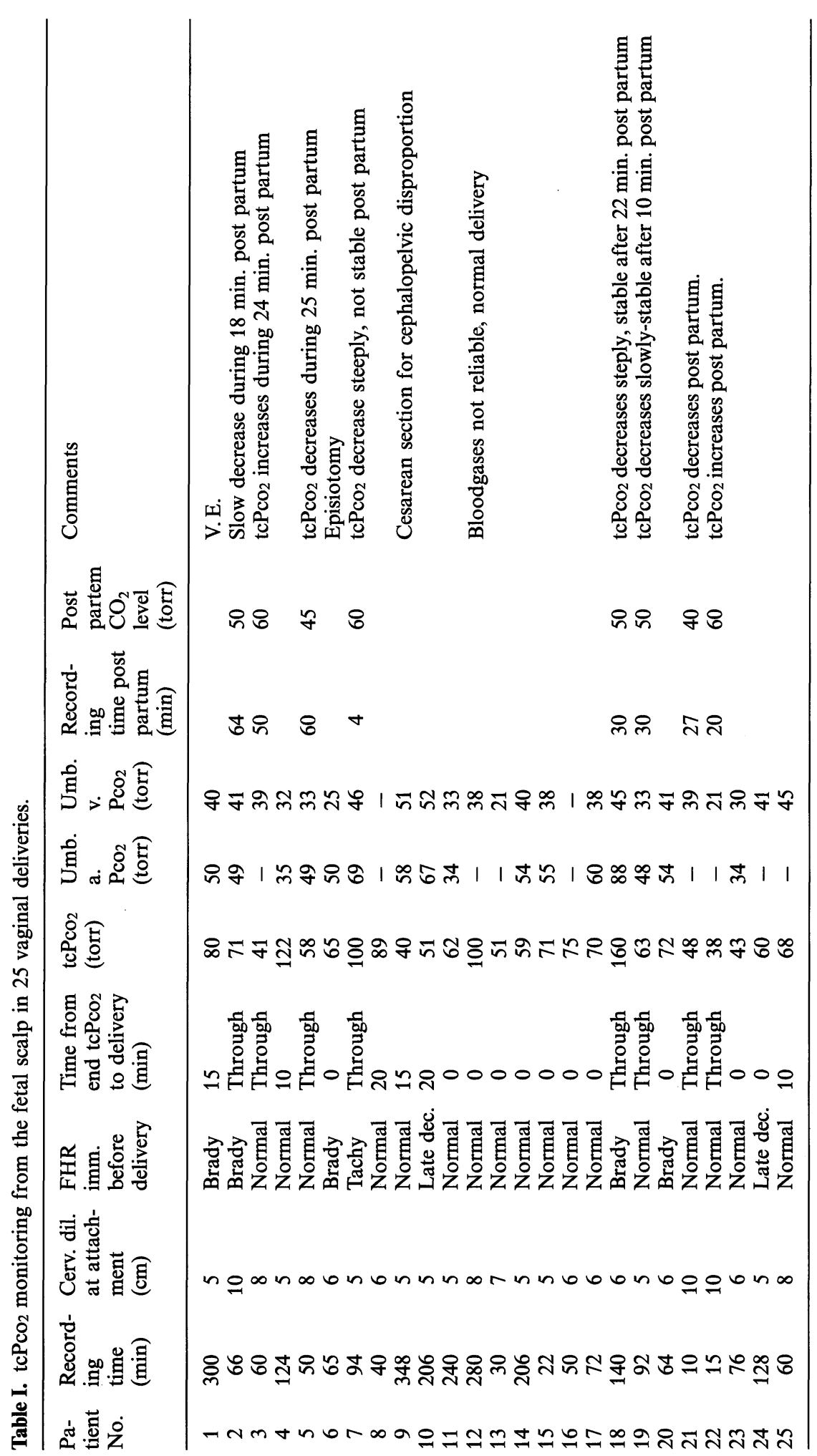




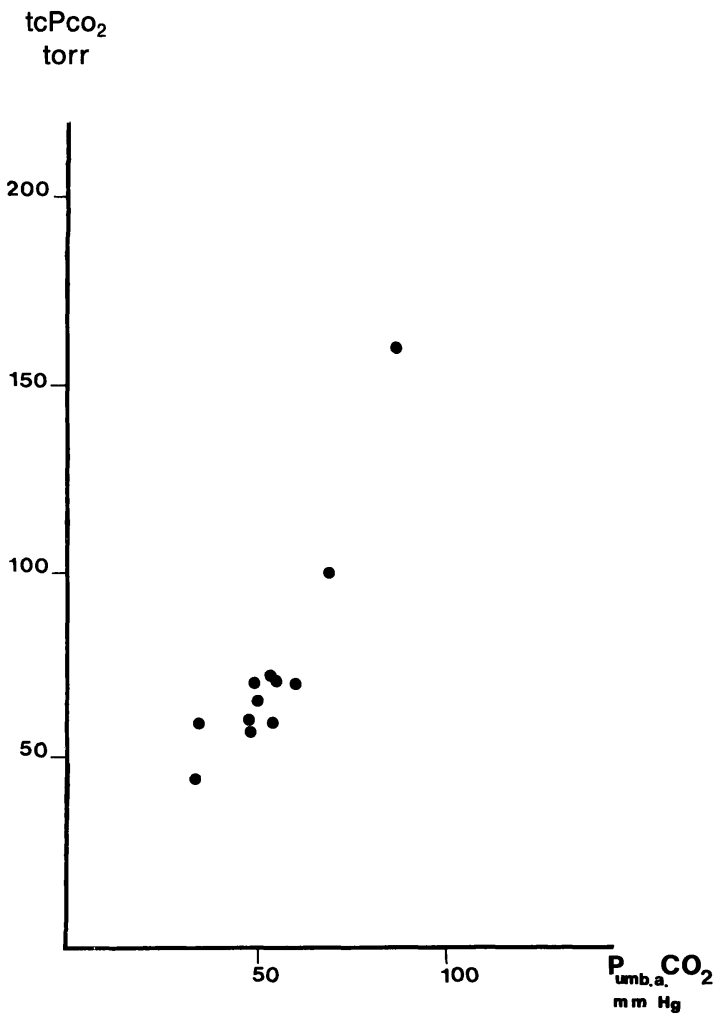

Figure 1. Correlation between $\mathrm{tcPco}_{2}$ at delivery and $\mathrm{PcO}_{2}$ in umbilical arterial blood obtained before the first breath.

was on the pelvic floor, while 8 of 25 patients were delivered with the electrode in situ. In 11 patients the electrode was removed just befors delivery of the fetal head. In 15 patients it was possible to obtain both a tcPco 2 value just before delivery and an umbilical cord blood sample before the first breath. In these 15 patients, there was a statistically highly significant correlation between $\mathrm{tcPcO}_{2}$ and umbilical artery $\mathrm{Pco}_{2}(\mathrm{r}=0.91 ; \mathrm{n}=12$; figure 1.). The correlation between $\mathrm{tcPcO}_{2}$ and $\mathrm{PcO}_{2}$ of umbilical venous blood was lower $(\mathrm{r}=0.58 ; \mathrm{n}=15$; figure 2.). The regression line between $\mathrm{tcPco}_{2}$ and $\mathrm{PCO}_{2}$ of umbilical blood deviated from the line of identity. Thus with increasing arterial $\mathrm{Pco}_{2}$, the $\mathrm{Pco}_{2}$ transcutaneousy measured rose more than proportionality. ( $\mathrm{P}_{\text {umb.a. }} \mathrm{CO}_{2} 1.3$ tcPco 2 and $\mathrm{Pum}_{\text {um. v. }} \mathrm{CO}_{2} 1.7$ tcPco 2 in fetuses with normal FHR - UC tracings.

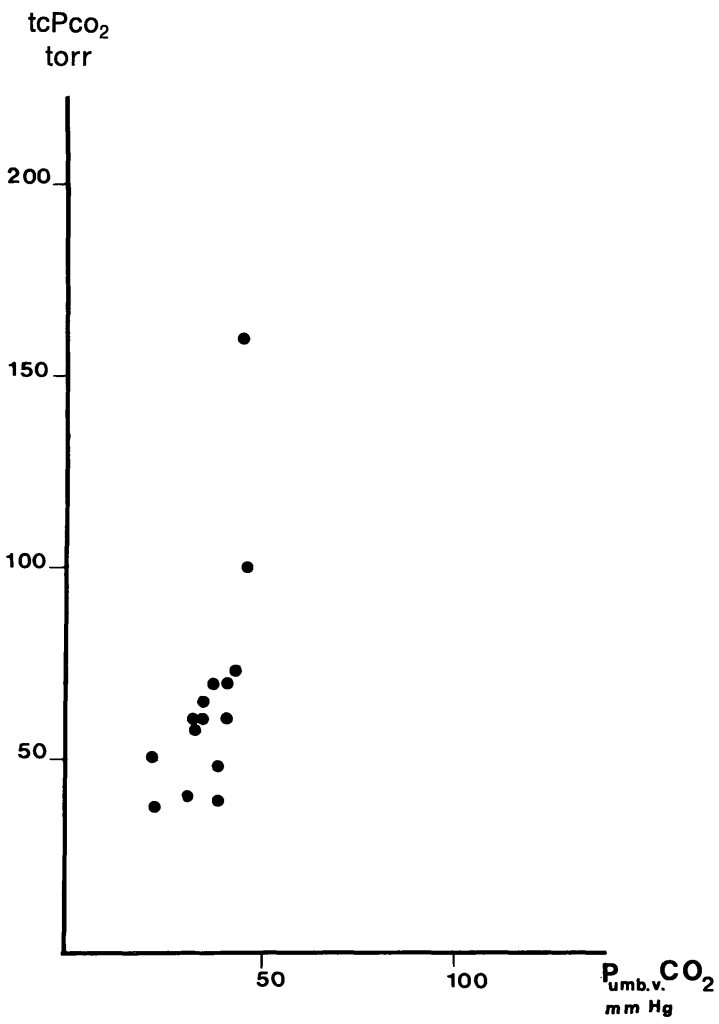

Figure 2. Correlation between $\mathrm{tcPco}_{2}$ at delivery and $\mathrm{PcO}_{2}$ in umbilical venous blood obtained before the first breath.

Figure 3 includes all recordings in the material. A mean $\mathrm{tcPco}_{2}$ level of 56 torr $(\mathrm{SD}=15)$ was calculated from 5 minute-to-minute values in each of 18 patients during the late first stage of labor. The mean tcPco 2 level at delivery in seven patients with a normal FHR - UC tracing was 61 torr $(\mathrm{SD}=9.3)$ with corresponding mean $\mathrm{Pco}_{2}$ values from the umbilical arterial and venous blood of 48 and 35 torr respectively. In five patients with varying types of FHR abnormalities, the mean $\mathrm{tcPco}_{2}$ was 94 torr with corresponding mean $\mathrm{Pco}_{2}$ of 62 torr and 42 torr from the umbilical arterial and venous blood. Although table I includes some with comparatively short FHR-UC abnormalities during the last portion of the second stage of labor, there did not seem to be a very good correlation between abnormalities and FHR - UC tcPco2 values (table I, compare patients no. 6-11, 


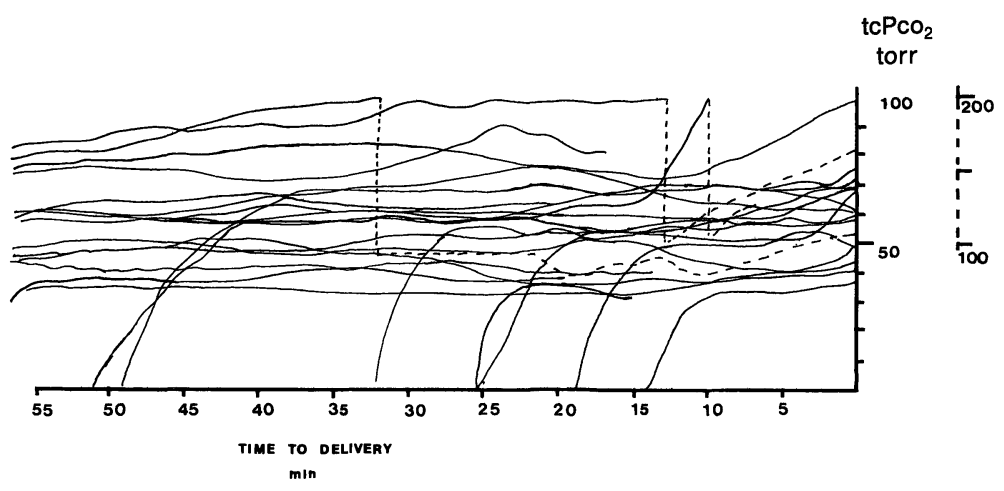

Figure 3. All recordings reported in the study. $\uparrow=$ change of scale.

$7-12,20-15,24-19)$. In only 3 of seven patients with FHR-UC abnormalities (one with tachycardia of $160 \mathrm{bpm}$ ) the tcPco2 level exeeded 80 torr. A tcPco 2 of 122 and 100 torr respectively was seen in two patients with normal FHR - UC tracings.

Eight fetuses were delivered with the electrode in situ. In seven of these the electrode was sufficiently attached for 20 minutes or more with a stable $\mathrm{tcPco}_{2}$ level (figure 4). The mean $\mathrm{tcPCO}_{2}$ values in the newborns after 20 minutes was 51 torr $(\mathrm{SD}=7.6)$. In 6 of 8 patients tcPco 2 decreased post partum, while in two newborns the level increased. The mothers of these two newborns were observed to hyperventilate vigorously during delivery.
One fetus (table I, no. 18, figures 4 and 5) showed the highest $\mathrm{tcPco}_{2}$ level recorded in the material in spite of an initially normal FHR - UC tracing. After about 40 minutes of recording there was a tachycardia of $150 \mathrm{bpm}$ and a few early decelerations (figure 5). During the last ten minutes, and after a further increase of $\mathrm{tcPco}_{2}$, suddenly there were variable decelerations and bradycardia, the fetal heart rate oscillated between 70 and $100 \mathrm{bpm}$. A forceps delivery was planned but not performed as the child was spontaneously delivered with the electrode in situ.

The tcPco 2 level at delivery was 160 torr and started to decline immediately after the first breath. As the child cried vigorously no ventila-

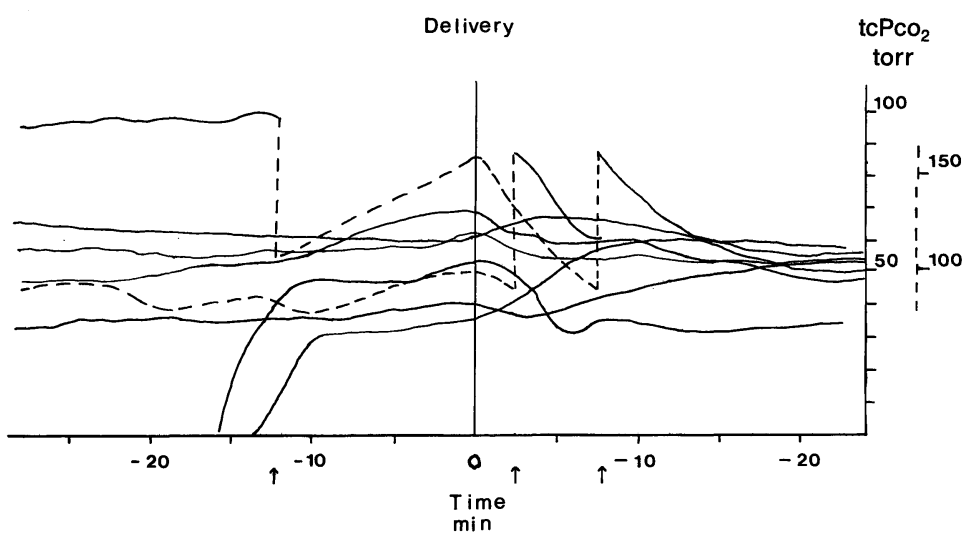

Figure 4. Eight recordings with the tcPcon electrode left in situ on the fetal/neonatal scalp until 20 min. post partum. $\uparrow=$ change of scale. 


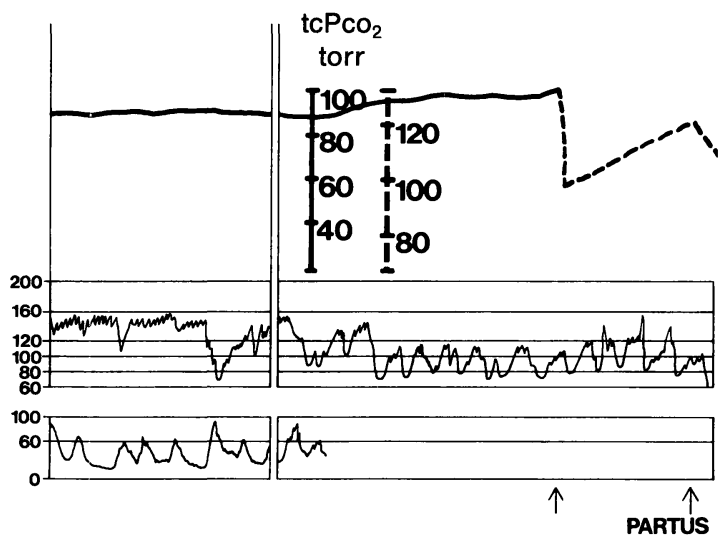

Figure 5. Fetal heart rate tracing with slight tachycardia and early decelerations in spite of an initially very high tcPco 2 level. After a further increase of $\mathrm{tcPcO}_{2}$ : a sudden bradycardia. Spontaneous delivery - see text; $\mathrm{pH}_{\mathrm{v}}$ / $\mathrm{pH}_{\mathrm{a}}=7.23 / 7.03 ; \mathrm{Pco}_{2} \mathrm{v} / \mathrm{a}=45 / 88$ torr; $\uparrow=$ change of scale; see also figure 4 .

tion was performed and the tcPco 2 level was stable at 50 torr after 22 minutes (figure 4). A $\mathrm{PcO}_{2}$ of the umbilical arterial and venous blood was 88 and 45 torr respectively and the $\mathrm{pH}$ was 7.03 and 7.23 respectively. The Apgar score at 1 minute was 9 .

Another child (no. 6, table I) demonstrated severe bradycardia ( $60 \mathrm{bpm}$ for 5 minutes) but a "normal" tcPco 2 level when the fetal head was just above the pelvic floor. Because of the FHR - UC pattern, an episiotomy was performed, and the child was spontaneously delivered. The tcPcon level was 65 torr with corresponding $\mathrm{Pco}_{2}$ levels of the umbilical arterial and venous blood of 50 and 35 torr respectively.

\section{Discussion}

From reports on transcutaneous oxygen monitoring is known that the relation between transcutaneous and arterial blood gas levels may vary among patients [9]. Thus, only the correlation obtained from different values in the same patient at the same measurement occasion should be justified as a measure of the relationship between arterial and transcutaneous values. From transcutaneous carbon dioxide measurements in neonatal intensive care units it is known that there is a rather constant relationship between $\mathrm{tcPcO}_{2}$ and $\mathrm{aPco}_{2}$ and also among different patients [8]. This also seems to be true in fetal measurements as there was a statistically significant correlation between tcPco 2 and $\mathrm{Pco}_{2}$ umbilical blood in this study. At least this was true for the correlation between $\mathrm{tcPcO}_{2}$ and $\mathrm{PcO}_{2}$ of the umbilical arterial blood. As the study was performed in a consecutive manner with "normal" patients, the two "occasional" high values might have a proportionately greater influence on the correlation coefficient and also on the slope of the regression line.

The attachment of the electrode was very adequate with Histoacryl ${ }^{\circledR}$ and it was possible to measure $\mathrm{tcPcO}_{2}$ in 19 of 25 patients until delivery of the fetal head. In a few of these patients, the electrode was deliberately removed because of possible risk for laceration of the vaginal introitus, while some electrodes were disattached by the wire working as a lever. No burns were produced from the electrode temperature of $44{ }^{\circ} \mathrm{C}$. It has been shown [8] that, with the current electrode, it is possible to measure tcPco 2 also at $37^{\circ} \mathrm{C}$ but such measurements were not performed in this present study.

In eight fetuses the application of the electrode in the middle of the presenting vertex, made delivery possible with the electrode in situ. Thus the change of $\mathrm{tcPco}_{2}$ could be recorded when the fetuses changed from placental to lung breathing. In 6 of 8 fetuses the postpartum tcPco 2 level decreased as compared to the antepartum level, while in 2 of 8 fetuses the level seemed to increase. The two mothers of these children were observed to hyperventilate vigorously during delivery.

Thus maternal hyperventilation may reduce fetal $\mathrm{Pco}_{2}$ resulting in neonatal hypoventilation immediately after birth. This should be considered in discussions concerning the maternal breathing pattern during labor.

The mean $\mathrm{tcPco}_{2}$ during the late second stage of labor (61 torr; $n=7$ ) was higher than the mean $\mathrm{tcPco}_{2} 20$ minutes post partum (51 torr; 
$\mathrm{n}=7$ ), which to some extent contradicts previous findings postulating that maximal neonatal hypercapnea is caused during the first minutes of life [1]. tcPco 2 levels in all seven newborns recorded more than 25 minutes post partum were stable within 20 minutes which is a little longer than the stabilization time reported by ENGSTRÖM et al. [1].

With the present electrode used in neonatal intensive care units, it has been shown that tcPco $_{2}$ is $1.3 \times \mathrm{aPco}_{2}[2,8]$. In the current study this was true for fetal umbilical arterial blood while the corresponding factor for umbilical venous blood was 1.7 .

The mean $\mathrm{Pco}_{2}$ of umbilical arterial venous blood in the current study does not differ considerably from those reported in the literature $[4,5]$. However, the range of $\mathrm{tcPco}_{2}$ recordings include both rather high and low levels, some levels being even lower than levels published for umbilical vein blood. In the two patients with extremely low antepartum tcPco 2 levels (table I, pat. no. 3 and 22) the postpartum level increased to 60 torr after about 20 minutes. Both mothers were observed to breath vigorously as reported above.

It has been proposed by КосH et al. [5] that the composition of umbilical cord blood at delivery does not reflect basal condition in utero but the disturbance of fetal blood gas exchanged during labor. The findings in the current study indicates that at least blood gases of the umbilical venous blood during certain circumstances may be questioned as representative for the fetal blood gas status at delivery.

In patients with a uteroplacental insufficiency from hypertonic contractions, $\mathrm{Pco}_{2}$ in the umbilical vein blood is probably representative of the blood delivered to the fetus, while, in a fetus with umbilical cord compression this may not be the case. An umbilical cord compression may thus start with a selective compression of the umbilical vein. If, at delivery, the compression is released, releasing an umbilical loop from around the fetal neck, arterialized blood is immediately pumped into the fetus with the next heart beat and umbilical vein samples obtained at delivery does then not reflect the fetal blood gases. Blood gases from the umbilical vein should thus not be used to describe the fetal blood gas situation in cases of suspected umbilical cord compression.

The "tonsure effect" suggested by O'CONNOR and Hytten [10] as a cause of low transcutaneous oxygen levels, has not been evaluated for $\mathrm{tcPCO}_{2}$ but is probably of minor importance. If, however, the $\mathrm{tcPCO}_{2}$ is pressed to the fetal scalp by the vaginal walls, the decrease of the capillary circulations results in an increase of the tcPco 2 level. For the same reason, attention should be given not to attach the tcPco $\mathrm{Cl}_{2}$ electrode to a caput succedaneum. As has been pointed out for $\mathrm{tcPo}_{2}$ [6] cutaneous vasoconstriction may also influence the $\mathrm{tcPcO}_{2}$ value.

One fetus, with an initially normal FHR - UC but with an extremely high tcPco level, after a further increase of $\mathrm{tcPcO}_{2}$ suddenly demonstrated a bradycardia. The child was acidotic at delivery but had a normal Apgar score. It seems obvious that the child was hypercapneic before the onset of bradycardia (table I, pat. no. 18, figures 4 and 5). Another child, recorded both before and after delivery showed a tcPco 2 level of about 100 torr at delivery while the FHR-UC tracing only showed a tachycardia (160 bpm), (table I, pat. no. 7). This child was also acidotic at delivery but had a normal Apgar score. In both children, the acidosis was of the respiratory type, and in both newborns there was an increase of the $\mathrm{tcPcO}_{2}$ level before the appearance of FHR - UC changes. In a third patient (table I, pat. no. 6) the tcPco $\mathrm{Cl}_{2}$ level was stable at 65 torr in spite of severe bradycardia some minutes before delivery. Fetal blood gases were normal as was the Apgar score. These cases reported indicate that both Apgar score and FHR - UC tracing are rather crude methods to judge the fetal blood gas status.

If a vaginal examination shows that the $\mathrm{tcPcO}_{2}$ electrode is neither pressed against the vaginal walls, nor attached on a caput succedaneum, the $\mathrm{tcPCO}_{2}$ measurement seem to reliably reflect 
true changes of blood $\mathrm{Pco}_{2}$ and an increase of fetal tcPCO 2 is then an early indication of fetal hypercapnea.

Although this method to study fetal blood gas changes and blood gas during the pulmonary adaptation period seems very reliable, for the time being it does not replace any other fetal surveillance method available. Further development of the technique and possibilities to construct an electrode for simultaneous $\mathrm{CO}_{2}$ and $\mathrm{O}_{2}$ monitoring [12], makes transcutaneous blood gas monitoring a potential tool for fetal routine surveillance during labor.

\section{Summary}

An electrode for continuous transcutaneous carbon dioxide $\left(\mathrm{tcPcO}_{2}\right)$ monitoring was attached to the fetal scalp in 25 consecutive vaginal deliveries. In six patients the electrode fell off or was deliberately removed when the fetal head was on the pelvic floor, while eight patients were delivered with the electrode in situ, making it possible to study changes in the fetal carbon dioxide level when the fetus changed from placental to lung breathing. The mean recording time was 136 minutes (range 10-348). Fifteen patients were recorded until delivery and analysis of cord blood showed a statistically highly significant correlation between $\mathrm{tcPco}_{2}$ in both

umbilical venous and arterial blood. The mean fetal tcPco 2 during the late first stage of labor was 56 torr (range $40-75 ; n=18$ ).

The post partum tcPco 2 level in newborns was stabel 20 minutes after delivery with a mean level of 51 torr (range $40-60)$. Fetuses with a normal fetal heart rate tracing showed a lower mean tcPcon level than fetuses with fetal heart rate tracing abnormalities. The experience with the current technique indicates that both Apgar score and fetal heart rate tracing are rather crude methods to judge fetal blood gas status.

Keywords: Fetal blood gas, fetal disease, fetus, labor, transcutaneous carbon dioxid.

\section{Zusammenfassung}

Kontinuierliche transkutane $\mathrm{CO}_{2}$-Messung in der Kopfschwarte unter der Geburt und während der ersten Lebensiminuten

Bei 25 aufeinanderfolgenden, vaginalen Entbindungen wurde eine Elektrode zur kontinuierlichen transkutanen $\mathrm{PcO}_{2}-\mathrm{Messung}\left(\mathrm{tcPcO}_{2}\right)$ am fetalen Skalp appliziert. In 6 Fällen fiel die Elektrode ab oder wurde beim Tiefertreten des Kopfes auf den Beckenboden langsam abgeschert, während 8 Feten mit der Elektrode in situ geboren wurden, so daß Veränderungen des fetalen $\mathrm{CO}_{2}$-Wertes beim Übergang von der Plazenta- zur Lungenatmung untersucht werden konnten. Die mittlere Aufzeichnungsdauer betrug 136 Minuten (Werte zwischen 10 und 348 Min.). Bei 15 Feten erfolgten Messungen bis zur Entbin- dung, und die Bestimmung des $\mathrm{Pco}_{2}$ in der Nabelvene zeigte eine statistisch hochsignifikante Korrelation mit dem Wert im arteriellen Blut. Der mittlere fetale $\mathrm{tcPcO}_{2}$ in der späten Eröffnungsperiode betrug 56 torr (Werte zwischen 40 und 75 torr; $n=18$ ).

Post partum stabilisierte sich der tcPcon-Wert bei den Neugeborenen nach 20 Minuten bei 51 torr (Werte zwischen 40 und 60 torr). Feten mit einem normalen CTG hatten niedrigere tcPcon-Spiegel als solche mit suspekten CTG's. Die Erfahrungen mit dieser neuen Technik zeigen, daß sowohl der Apgar-Score wie auch das CTG relativ grobe Parameter zur Beurteilung der fetalen Blutgase darstellen.

Schlüsselwörter: Fetale Blutgase, fetale Pathologie, Fetus, Geburt, transkutanes $\mathrm{CO}_{2}$.

\section{Résumé}

Mesure continue transcutanée du dioxyde de carbone au scalp fetal pendant le travail et durant les premières minutes de vie

Au cours de 25 accouchements par voie basse, consécutifs, on a mis en place, sur le scalp fœtal, une électrode pour surveiller en continu, par voie transcutanée, le dioxyde de carbone (tcPco 2 ). Chez 6 patientes l'électrode est tombée ou a été enlevée de façon délibérée lorsque la tête fœtale était au niveau du plancher pelvien; 8 patientes ont accouché avec l'électrode en place ce qui a rendu possible l'étude des modifications des taux de dioxyde de carbone fœtaux lorsque le fœtus passe de l'oxygénation placentaire à la respiration pulmonaire. Le temps d'enregistrement moyen est de 136 minutes (écarts de 10 à 348). 15 patientes ont été enregistrées jusqu'à l'accouchement et l'analyse au sang du cordon a montré une corrélation statistiquement hautement significative entre la $\mathrm{tcPco}_{2}$ et la $\mathrm{Pco}_{2}$ dans la veine et 
dans l'artère ombilicale. $\mathrm{La}$ tcPco 2 fotale moyenne à la fin de la phase de dilatation est de 56 torr (extrêmes $=40$ et $75 ; \mathrm{n}=18$ ).

Les valeurs de la tcPco 2 chez les nouveaux-nés dans le post-partum se stabilisent 20 minutes après l'accouchement avec une valeur moyenne de 51 torr (extrêmes $=40$ et 60). Les fœtus dont le cardiotocogramme est normal présentent un $\mathrm{tcPcO}_{2}$ dont la valeur moyenne est plus basse que celle des fotus dont le cardiotocogramme est anormal. L'expérience courante indique que le score d'Apgar et le cardiotocogramme sont des instruments plûtot imprécis pour juger de l'équilibre des gaz sanguins du fœtus.

Mots-clés: Fœtus, gaz du sang fœtaux, dioxyde de carbone transcutané, maladie fœtale, travail.

\section{References}

[1] Engström L, P Karlberg, G RoOth, R Tunell: The onset of respiration, a study of respiration and changes in blood gases and acid base balance. Association for the aid of crippled children, 1966

[2] Hansen TN, WH Tooley: Skin surface carbon dioxide tension in sick infants. Pediatrics 64 (1979) 942

[3] Huch A, R Huch, H Schneider, G Rooth: Continuous transcutaneous monitoring of fetal oxygen tensions during labor. Br J Obstet Gynaecol [Suppl] 84 (1977) 1

[4] Kirschbaum TH, JC DeHaven: Maternal and fetal blood constituents. In: Assali NS (ed): Biology of Gestation, pp. 143. Academic Press, New York 1968

[5] Косн G, H Wendel: Adjustment of arterial blood gases and acid base balance in the normal newborn infant during the first week of life. Biol Neonate 12 (1968) 136

[6] LöFGREN O: Continuous transcutaneous carbon dioxide monitoring in the fetus during labor. Crit Care Med 9 (1981) 750

[7] LöFGREN O: Continuous transcutaneous oxygen monitoring in fetal surveillance during labor. Am J Obstet Gynecol 141 (1981) 729

[8] LÖFGREN O, D ANDERSSON: Simultaneous transcutaneous carbon dioxide and transcutaneous oxygen monitoring in neonatal intensive care. J Perinat Med 11 (1983) 51

[9] LÖFGREN O, P HeNRIKSSON, L JACOBSON, Ö JohANSSON: Transcutaneous $\mathrm{Po}_{2}$ monitoring in neonatal intensive care. Acta Paediatr Scand 67 (1978) 693
[10] O'CONNOR MC, FE HytTEN: Measurement of fetal transcutaneous oxygen tension - problems and potentials. Br J Obstet Gynaecol 86 (1979) 948

[11] SALing E, D SChNeIDER: Biochemical supervision of the fetus during labor. J Obstet Gynaecol $\mathrm{Br}$ Commonw 74 (1967) 799

[12] Schmidt S, K Langner, JW Dudenhausen, E SalING: Reliability of transcutaneous measurement of oxygen and carbon dioxide partial pressure with a combined $\mathrm{Po}_{2} / \mathrm{Pco}_{2}$ electrochemical sensor in the fetus during labor. J Perinat Med 13 (1985) 127

[13] TREMPER K: $\mathrm{P}_{\mathrm{tc}} \mathrm{O}_{2} / \mathrm{P}_{\mathrm{tc}} \mathrm{CO}_{2}$ monitoring in respiratory and circulatory failure in adult chock patients. 3rd World Congress of Critical Care Medicine, Washington 1981

[14] Weber T, S Hahn-Pedersen, JE Bock: Continuous fetal tissue $\mathrm{pH}$ recordings during labor - A preliminary report. Br J Obstet Gynaecol 85 (1978) 770

[15] Willcourt RJ, JC KING, JT QuEEnAN: Maternal oxygenation administration and fetal transcutaneous $\mathrm{Po}_{2}$. Am J Obstet Gynecol 141 (1983) 714

Received March 23, 1985. Revised April 21, 1986. Accepted May 13, 1986.

Olof Löfgren, M. D.

Delivery Ward

County Hospital of Trelleborg S-231 00 Trelleborg

Sweden 